\title{
PEMENUHAN NAFKAH PAKAIAN DARI SUAMI KEPADA ISTRI (Studi Kasus Warga RT. 25 Kelurahan Teritip Kecamatan Balikpapan Timur)
}

\author{
Isaliyah \\ Sekolah Tinggi Ilmu Syariah Hidayatullah Balikpapan \\ Isaliyah34@gmal.com \\ Paryadi \\ Sekolah Tinggi Ilmu Syariah Hidayatullah Balikpapan \\ semangatmas@gmail.com
}

\begin{abstract}
Abstrak
Pemenuhan nafkah pakaian merupakan kewajiban bagi suami, namun tidak semua suami pada warga RT. 25 memberikan nafkah pakaian kepada istrinya. Metode penelitian yang digunakan adalah penelitian kualitatif. Jenis penelitian yang digunakan adalah studi kasus. Pemenuhan nafkah pakaian Warga RT. 25 Kelurahan Teritip dapat di bagi menjadi tiga kelompok. Pertama, tiga kasus nafkah pakaian yang terpenuhi. Suami berpenghasilan yang cukup dan suami telah mengetahui kewajibannya. Kedua, empat kasus nafkah pakaian yang kurang terpenuhi karena kelalaian suami serta menganggap pakaian bukan hal utama. Ketiga, tujuh kasus suami tidak memenuhi nafkah pakaian kepada istri. Suami yang tidak memberikan nafkah pakaian kepada istri dengan alasan bahwa nafkah pakaian bukan hal yang penting sehingga mendahulukan kebutuhan yang lain tidak dibenarkan dalam syariat. Adapun suami yang berpenghasilan minim dan suami yang tidak mengetahui bahwa nafkah pakaian merupakan kewajiban bagi suami, maka alasan ini adalah udzur, syariat tidak membebani hamba yang tidak mampu dan tidak mengetahui.
\end{abstract}

\section{Keywords: pakaian, nafkah, suami}

\section{A. Pendahuluan}

Pernikahan merupakan salah satu sunnatullah yang berlaku pada semua makhluk-Nya, baik manusia, hewan, maupun tumbuh-tumbuhan. Pernikahan juga sebagai suatu cara yang dipilih Allah swt sebagai jalan bagi manusia untuk beranak, berkembang biak, dan melestarikan kehidupannya, setelah masing-masing pasangan siap melakukan peranannya yang positif dalam mewujudkan tujuan pernikahan. ${ }^{1}$ Sebagaimana firman Allah swt dalam Q.S. Yasin [36] : 36,

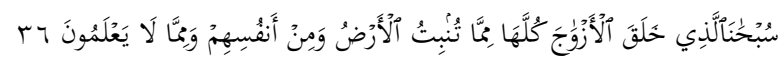

"Maha Suci Tuhan yang telah menciptakan pasangan-pasangan semuanya, baik dari apa yang ditumbuhkan oleh bumi dan dari diri mereka maupun dari apa yang tidak mereka ketahui."

1 Sayyid Sabiq, Fikih Sunnah, Jilid II, (Jakarta: Pena Pundi Aksara, 2007), cet. Ke-2, h. 477. 
Ayat di atas menunjukkan bahwa manusia diciptakan oleh Allah swt untuk menaati perintah-Nya dan melaksanakan sunnah Nabi, salah satunya melalui sebuah pernikahan untuk menyalurkan kebutuhan jasmani maupun rohani berdasarkan syariat Islam.

Pernikahan adalah fitrah manusia, oleh karena itu, Islam menganjurkan ummatnya untuk menikah karena nikah merupakan naluri kemanusiaan. Apabila naluri ini tidak dipenuhi dengan jalan yang sah, yaitu pernikahan, maka ia akan mencari jalan-jalan syaitan yang menjerumuskan manusia ke lembah hitam. ${ }^{2}$

Sistem keluarga yang bijaksana dan seimbang adalah dasar utama kehidupan yang bahagia. Kehadiran agama dimaksudkan untuk lebih mendekatkan manusia kepada Allah swt. Agama tidak dianggap sempurna jika tidak mempunyai tata cara kehidupan keluarga yang tegas, yang mampu mengungkapkan dengan jelas dan pasti mengenai tanggung jawab dan peranan masing-masing. ${ }^{3}$

Agama Islam telah memberikan beberapa ketentuan mengenai kewajiban suami dalam berkeluarga diantaranya nafkah. Nafkah adalah pemenuhan kebutuhan istri berupa makanan, pakaian, tempat tinggal, pelayanan, dan pengobatan meskipun istri berkecukupan. Pakaian termasuk bagian dari nafkah yang merupakan kewajiban bagi suami, sesuai dengan ketentuan al-Quran, sunnah dan al-Ijma :4 Allah swt berfirman dalam Q.S Al-Baqarah [2] : 233.

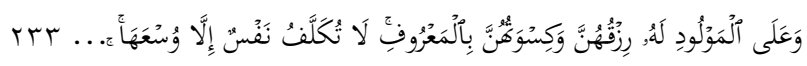

"Dan kewajiban ayah memberi makan dan pakaian kepada para ibu dengan cara ma'ruf seseorang tidak dibebani lebih dari kesanggupannya."

Pernikahan bisa dikatakan langgeng dan tetap harmonis, jika keduanya saling mengerti tanggung jawab masing-masing, namun terkadang hal tersebut tidak berjalan sesuai dengan rencana. Kebanyakan suami justru melalaikan kewajibannya dalam memberikan nafkah pakaian. Nafkah pakaian merupakan bagian dari nafkah lahir yang wajib dipenuhi suami kepada istri. Kategori nafkah lahir dalam buku Minhajul Muslim yaitu: makanan, pakaian dan tempat tinggal yang diberikan kepada orang yang wajib diberinya. ${ }^{5}$

Melihat bahwa nafkah pakaian merupakan kewajiban yang diperintahkan Allah swt dalam al-Quran dan sunnah, di sisi lain pakaian merupakan kebutuhan yang

2 Yasin bin Abdul Qadir Jawas, Panduan Keluarga Sakinah, (Jawa Barat: Pustaka At-Taqwa, 2005), cet. Ke-5, h. 11.

${ }^{3}$ Hidayat Nataatmadja, Keluarga Islam, (Bandung: Risalah, 1198), h. 13.

4 Sayyid Sabiq, Fiqhus Sunnah, jilid III, terj. Mujahidin Muhayan, Fikih Sunnah, (Jakarta: Cakrawala Publishing, 2008), h. 427.

${ }^{5}$ Abu Bakar Jabir Al-Jaza`iri, Minhajul Muslim, (Beirut: Daru al-Fikr, 1419 H), h. 340. 
penting bagi istri, dan merupakan kebiasaan para istri warga RT. 25 memakai pakaian gamis, karena dengan berpakaian gamis, perintah menutup aurat dapat diterapkan dan dijalankan.

Nafkah pakaian sangat diperlukan bagi istri untuk memenuhi kebutuhannya, namun kewajiban itu bukan disebabkan oleh karena istri membutuhkannya, akan tetapi kewajiban yang timbul karena perintah syariat, tanpa melihat kepada keadaan istri, jadi nafkah pakaian harus diberikan tanpa istri harus meminta terlebih dahulu kepada suami.

Peneliti mengambil lokasi di RT. 25, karena mayoritas masyarakat yang berdomisili di tempat tersebut merupakan orang-orang yang memahami syariat dan termasuk warga yang diberikan amanah sebagai da'i yang bertugas untuk lembaga, sehingga pesantren menfasilitasi rumah tersebut dengan tujuan agar memudahkan para da'i dalam menjalankan tugasnya, dengan demikian bagi seorang suami sepantasnya bisa memberi nafkah pakaian kepada istrinya. Kenyataan yang telah terjadi di masyarakat tidak semua suami memberikan nafkah pakaian kepada istri. Melihat fenomena tersebut peneliti tertarik untuk mengkaji system pemenuhan nafkah pakaian dari suami kepada istri dalam tinjauan Hukum Islam.

\section{B. Metode Penelitian}

Penelitian ini menggunakan penelitian kualitatif, yaitu sebuah metode penelitian yang dalam pengumpulan dan analisisnya menggunakan data naratif bukan angka. Penelitian ini merupakan penelitian studi kasus terhadap kejadian permasalahan nafkah kiswah bagi istri di RT 25 kelurahan Teritip.

Sumber data dalam penelitian ini berasal dari responden, informan, data publikasi daerah, dan data-data kepustakaan. Adapun data yang digunakan adalah hasil wawancara, observasi, dan angket.

Teknik yang peneliti gunakan dalam penelitian ini adalah Deksriptif Analitik. Yaitu teknik penelitian dengan menjelaskan terlebih dahulu gambaran objek penelitian secara naratif kemudian dianalisa menggunakan pisau analisis pada pembahasan teori.

\section{Kewajiban Memenuhi Nafkah dalam Islam}

Ada beberapa definisi nafkah yang dikemukakan ulama fiqh, tetapi seluruh definisi tersebut mengandung esensi yang sama meskipun redaksionalnya berbeda. Menurut ulama Mazhab Hanafi, nafkah adalah melimpahkan kepada sesuatu dengan 
hal yang menyebabkan kelanggengan. ${ }^{6}$ Adapun menurut Kamus Besar Bahasa Indonesia nafkah adalah pendapatan suami yang wajib diberikan kepada istri. ${ }^{7}$

Beberapa pengertian di atas, maka dapat disimpulkan bahwa nafkah adalah semua pengeluaran pembelanjaan seseorang atas orang yang menjadi tanggung jawabnya untuk memenuhi kebutuhan pokok yang diperlukan. Kebutuhan pokok yang dimaksud adalah kebutuhan pangan, kebutuhan sandang (pakaian) dan kebutuhan papan (tempat tinggal).

Hukum nafkah tercantum dalam beberapa ayat dalam al-Quran yang menjadi dasar nafkah secara umum, terkhusus pada kewajiban-kewajiban yang timbul sebagai akibat terjadinya hubungan perkawinan. Pemberian nafkah disini yaitu semua macam belanja yang dikeluarkan oleh suami untuk memenuhi keperluan istri dan anak-anaknya. ${ }^{8}$

Allah swt berfirman dalam Q.S. Al-Baqarah [2] :233.

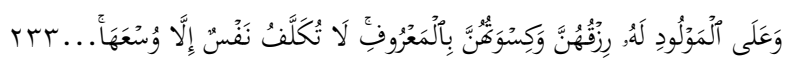

Ayat tersebut telah menegaskan bahwa ayah diwajibkan menanggung segala kebutuhan makan dan pakaian ibu yang menyusui anaknya sekalipun telah diceraikan oleh ayah anaknya, jika terhadap mantan istri yang masih menyusui anaknya wajib untuk diberikan nafkah, apalagi terhadap perempuan yang sah menjadi istrinya tentu lebih patut untuk diberi nafkah. ${ }^{9}$

Maksud dari ayat tersebut "Al Maulud" yang berarti ayah dan Ar-Rizqi maksudnya makanan secukupnya dan kiswah adalah pakaian. Pada kata al-ma`ruf adalah tidak terlampau kikir dan tidak berlebihan. ${ }^{10}$ Adapun pada hadis yang menerangkan tentang kewajiban seorang suami memberi nafkah yaitu:

عن جابر رضى الله عنه عن النبى صلى الله عليه و سلم في حديث الحج بطوله قال في ذكر النساء : ولن عليكم رزقهن وكسوقن بالمعروف(اخرجه

مسلم)

"Dari Jabir ra, Nabi saw bersabda pada waktu melaksanakan ibadah haji, beliau mengingatkan kepada para suami tentang perkara seorang perempuan, beliau bersabda: "Mereka mempunyai hak rezeki dan pakaian atas kalian dengan cara yang ma 'ruf."

\footnotetext{
${ }^{6}$ Ana Sofiatul Fitri, "Pandangan Hakim Terhadap Penentuan Nafkah Akibat
} Perceraian (Studi di Pengadilan Agama Kota Malang dan Pengadilan Agama Kabupaten Malang) (Tesis, UIN Maulana Malik Ibrahim, Malang), 40.

7 Tim Redaksi Kamus Besar Bahasa Indonesia, Kamus Besar Bahasa Indonesia, (Jakarta: PT Gramedia Pustaka Utama, 2008), h. 947.

${ }^{8}$ Muhammad Thalib, Ketentuan Nafkah Istri dan Anak, (Bandung: Irsyad Baitus Salam, 2000), cet. Ke-1, h. 19.

${ }^{9}$ Ibid

${ }^{10}$ H.S.A. Al Hamdani, Risalah nikah, (Jakarta: Pustaka Amani, 2002) , cet. Ke-2, h. 114.

${ }^{11}$ Muslim bin al- Hajjaj Abu al- Husain al- Qusyairi an- Naisaburi, Șahih Muslim, (Beirut: Dar Ihya at- Turats al- Araby, tt), h. 886. 
Keempat Imam Mazhab yaitu Maliki, Hanafi, Syafii dan Hambali sepakat bahwa memberikan nafkah itu hukumnya wajib setelah adanya ikatan pernikahan. Keempat Imam Mazhab tersebut sepakat bahwa nafkah itu meliputi pakaian, makanan dan tempat tinggal. ${ }^{12}$

Untuk mendapatkan nafkah harus dipenuhi beberapa syarat, apabila tidak terpenuhi, maka tidak berhak menerima nafkah. Syarat-syarat sebagai berikut:

a. Akadnya sah dan perempuan itu sudah menyerahkan dirinya kepada suaminya serta istri memungkinkan bagi suami untuk dapat menikmati dirinya. Istri tidak keberatan pindah tempat apabila suami menghendakinya, kecuali apabila suami bermaksud jahat dengan kepergiannya itu atau tidak membuat aman dari si istri dan kekayaannya, atau pada waktu akad sudah ada janji untuk tidak pindah dari rumah istri atau tidak akan pergi dengan istrinya.

b. Istri tersebut orang yang telah dewasa telah layak melakukan hubungan senggama dan apabila syarat-syarat itu tidak terpenuhi, maka suami tidak berkewajban memberi nafkah kepada istrinya. ${ }^{13}$

Sebab diwajibkannya memberikan nafkah ada tiga sebab, antara lain: Pertama, sebab pernikahan, syariat Islam mewajibkan suami memberi nafkah kepada isrti karena berdasarkan akad nikah yang sah. Kedua, sebab kekerabatan, jika saudara dekat orang yang tidak mempunyai harta, belum baligh dan belum bekerja, lanjut usia, gila dan sakit maka wajib di beri nafkah. ${ }^{14}$ Kemudian ketiga sebab kepemilikan yaitu adanya tuan dengan hamba sahaya, jika manfaat dari pekerja telah diperoleh dari sang pemilik, maka nafkah budak menjadi tanggungan tuannya. ${ }^{15}$

Istri yang tidak berhak menerima uang belanja atau nafkah menurut pendapat jumhur ulama yaitu:

a. Istri yang masih kecil yang belum dicampuri meskipun ia sudah bersedia untuk dicampuri. Sebaliknya, kalau yang masih kecil suaminya sedangkan istrinya sudah balig, maka nafkah wajib dibayar. Menurut pendapat Abu Hanifah dan Imam Syafii. ${ }^{16}$

${ }^{12}$ Abdurrahman Al-Juzairi, Fiqih `Ala Mażahib al-Arba`ah, Juz IV, (Mesir: Al-Maktabah Al-Tijariyyah Al Kubro, 1969 H), h. 553.

${ }_{13} \mathrm{Ibid}$, h. 147.

${ }^{14}$ Ibnu Qudamah, al- Maqdisi, al- Kahfi fi Fiqih Imam Ahmad, (Beirut: Dar al-Kutub alIImiyyah, 1990), cet. Ke-1, h. 257.

${ }^{15} \mathrm{Ibid}$, h. 56.

${ }^{16}$ Abdurrahman Al-Juzairi, Fiqih `ala al-Mazahib al-Arba`ah, Juz IV, (Beirut: Dar Fikr, 1406 H), h. 565. 
b. Apabila istri berpindah dari suaminya ke rumah lain tanpa alasan syar i atau pergi tanpa izin suami dan apabila istri nusyuz, durhaka atau berbuat maksiat terhadap suaminya atau tidak mau meladeni suaminya. ${ }^{17}$

c. Apabila istri bekerja atau membuka usaha sedangkan suami melarangnya untuk bekerja dan istri tidak memperhatikan larangan suaminya dan juga apabila si istri diculik sehingga berpisah dengan suaminya dan dipenjara karena melakukan kejahatan atau karena tidak membayar hutangnya. 18

Ibnu Rusyd dalam kitabnya Bidayah al-Mujtahid, telah mengungkapkan pendapat Imam Malik dan Abu Hanifah, bahwa ketentuan ukuran nafkah tidak ditentukan oleh syara', dan sesungguhnya nafkah itu dikembalikan pada keadaan suami dan istri. ${ }^{19}$ Allah swt berfirman dalam Q.S. At -Ṭhalaq [65] : 7.

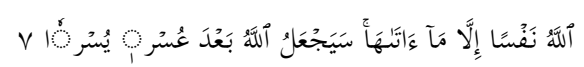

"Hendaklah orang yang mampu memberi nafkah menurut kemampuannya. Dan orang yang disempitkan rezekinya hendaklah memberi nafkah dari harta yang diberikan Allah kepadanya. Allah tidak memikulkan beban kepada seseorang melainkan sekedar apa yang Allah berikan kepadanya. Allah kelak akan memberikan kelapangan sesudah kesempitan."

Ayat tersebut di atas tidak memberikan ketentuan yang jelas mengenai berapa besarnya ukuran nafkah suami yang diberikan kepada keluarga baik berupa batas maksimal maupun batas minimal, namun jika suami memiliki keluasan rezeki, maka suami harus memberikan dan memperbanyak jatah nafkah anak dan istrinya. Kadar nafkah tersebut disesuaikan dengan kondisi suami dan kebutuhan istri.

Pendapat golongan Hanafi suami memberikan nafkah istri secukupnya seperti makanan, daging, sayur-mayur, buah-buahan dan segala yang diperlukan istri sehari-hari sesuai dengan keadaan umum, juga wajib bagi suami memberikan pakaian kepadanya. ${ }^{20}$

Imam Syafii berpendapat bahwa, bagi suami yang kaya ditetapkan kewajiban nafkah setiap hari dua mud, sedangkan untuk yang miskin ditetapkan kewajiban nafkah setiap hari satu mud, dan bagi yang sedang satu setengah mud. ${ }^{21}$ Mazhab Syafii berpendapat bahwa nafkah minimal yang harus dikeluarkan suami kepada istri adalah yang dapat memenuhi kebutuhan pokok berupa makanan, pakaian dan tempat tinggal. ${ }^{22}$

\footnotetext{
${ }^{17}$ Ibid, h. 572.

${ }^{18}$ Ibid, h. 573.

${ }^{19}$ Ibnu Rusyd, Bidayah al-Mujtahid, (Semarang: Asy-Syifa', 1990), h. 456.

${ }^{20}$ Ibid, h. 554.

${ }^{21}$ Al-Imam Abi Abdillah Muhammad Ibnu Idris asy-Syafi ’ i, Al Umm, Jilid VII, (Beirut:

${ }^{22}$ Abdurrahman Al-Juzairi, Fiqih `ala al-Mazahib al-Arba`ah, Juz IV, (Beirut: Dar Fikr,
} Darul Wafa', 1393 H), h. 231. 
Pakaian dari kamus Lisan al-`Arab yaitu الكسوة atau اللباس , memiliki arti pakaian yang dikenakan, pencampuran, amal șalih, malu dan menutupi. ${ }^{23}$ Al-Quran menggunakan istilah pakaian terdiri dari tiga kategori yaitu Libas (memakai), silyab (sesuatu yang dipakai) dan sarabil (gamis).24 Menurut Kamus Besar Bahasa Indonesia menjelaskan bahwa pakaian adalah barang yang dipakai atau sesuatu yang di kenakan seperti baju, celana, rok dan sebagainya. ${ }^{25}$

Kadar pemenuhan nafkah pakaian menurut ulama, suami diwajibkan memberi pakaian untuk istrinya, agar dapat menutup aurat, serta menahan dirinya dari cuaca, baik musim panas atau musim dingin. Bentuk teknis dari memberi pakaian bisa bermacam-macam, bisa dengan cara suami membuat sendiri dengan menjahit pakaian untuk istrinya, atau pun di masa industri sekarang ini, pakaian bisa dengan mudah dibeli yang sudah jadi. ${ }^{26}$

Menurut Malikiyyah nafkah pakaian diberikan tiap awal tahun dengan cara diserahkan dan tidak ada kewajiban mengganti jika pakaian itu dicuri ataupun rusak. ${ }^{27}$ Pendapat ini sama dengan mazhab Hanabilah menyebutkan minimal suami memberi pakaian kepada istrinya setahun sekali, karena hal itu merupakan adat atau kebiasaan yang berlaku umum dimana-mana ${ }^{28}$.

Menurut Imam Asy-Syirazi bahwa suami wajib memberikan pakaian kepada istrinya pada setiap enam bulan sekali dengan makna yang lain dua kali dalam setahun. Bilangan minimum pakaian yang wajib yaitu tiga helai pakaian pada musim panas dan empat pada musim sejuk yaitu gamis yang menutup seluruh badan, qina'(tudung) penutup kepala, kain penutup badan dan jubah pada musim sejuk, dan termasuk kategori pakaian yang wajib yaitu selimut, bantal, tikar, hamparan permadani yang tebal untuk tidur dan keperluan lain. ${ }^{29}$

Menurut mazhab Asy-Syafii menyebutkan bahwa seorang suami diwajibkan memberi pakaian kepada istrinya minimal enam bulan sekali ${ }^{30}$. Begitu juga menurut Hanafiyyah, nafkah pakaian diberikan tiap enam bulan sekali karena umumnya

1406 H), h. 563

${ }^{23}$ Muhammad bin Mukarram bin Manẓur al-Mișri, Lisan al-Arab, Juz. IV, (Beirut: Dar Shadir, 1996), h. 202-204.

${ }^{24}$ Quraish shihab, Wawasan Al-Quran, (Bandung: Mizan, 2001), h. 155.

${ }^{25}$ Tim Prima Pena, Kamus Besar Bahasa Indonesia, (tp : Gita media Press, tt), h. 570.

${ }^{26}$ Ahmad Sarwat, Seri Fikih Kehidupan Pernikahan, Jilid VIII, (Jakarta: Rumah Fikih Publishing, 2017), h. 179

${ }^{27}$ Wahbah azuhaili, al-Fiqih al-Islami wa adilatuha, (Damaskus: Darul fikr, 2007 M), h.7389)

${ }^{28}$ Abdurrahman Al-Juzairi, Fiqih `ala al-Mazahib al-Arba`ah, Juz IV, (Beirut: Dar Fikr, 1406 H), h. 584.

${ }^{29}$ Abu Ishaq asy-Syiraziy, Al-Muhażab fi fiqih al-Imam asy-Syafi $i$ i, Jilid IV, (Damaskus: Darul asy-Syamiyah: 1996 M ), h. 612.

${ }^{30}$ Abdurrahman Al-Juzairi, Fiqih `ala al-Mazahib al-Arba `ah... h. 561. 
pakaian itu rusak setelah enam bulan. Pakaian tersebut jika sudah rusak sebelum enam bulan maka tidak wajib bagi suami untuk menggantinya, sebagaimana tidak wajib mengganti makanan yang sudah habis sebelum habisnya hari. ${ }^{31}$

Suami juga diwajibkan memberikan pakaian yang baru, jika pakaian yang diberikan tidak dapat tahan lama dalam satu tahun, seperti suami memberikan pakaian baru kepada istrinya setiap enam bulan sekali guna memperbaruhi pakaiannya. Pakaian istri apabila rusak pada pertengahan musim, sekalipun bukan karena kecerobohan pihak si istri, pihak suami tidak wajib menggantinya dengan yang baru, sehingga memberikan ganti pakaian kepada istri diwajibkan pakaian yang masih baru bukan bekas karena istri dapat menuntut untuk dibelikan pakaian baru jika pakaian tersebut rusak dan tidak tahan lama. ${ }^{32}$

Kesimpulan dari beberapa pendapat ulama bahwa nafkah wajib diberikan kepada istri dengan ketentuan ideal suami memberi istri pakaian setiap enam bulan sekali atau satu tahun sekali sesuai dengan kebiasaan yang berlaku dan menurut keumuman ketahanan pakaian.

\section{Hasil Penelitian}

Kelurahan Teritip di kecamatan Balikpapan Timur berada di wilayah paling ujung dari kota Balikpapan yang berbatasan dengan Kabupaten Kutai Kertanegara. Kondisi topografi 70\% dari luas Kelurahan Teritip merupakan daerah perbukitan dengan ketinggian 75 meter dari permukaan laut dan 25\% merupakan daerah dataran rendah yang sempit dan berada di antara perbukitan dan pesisir pantai sedangkan $5 \%$ adalah laut.

Rata-rata pertumbuhan penduduk pada periode 2016-2017 sebanyak 0,005 $\%$ pertahun. sedangkan penduduk Kelurahan Teritip pada tahun 2016 berjumlah 13.907 jiwa, kemudian pada tahun 2017 berjumlah 14.509 jiwa, dan pertumbuhan penduduk tahun 2016-2017 sebesar 719 jiwa pertahun.

Pemenuhan nafkah pakaian dari suami kepada istri warga RT. 25 terbagi menjadi tiga katergori, yaitu pemenuhan nafkah pakaian yang terpenuhi, terdapat pada kasus VII, X dan XI dan pemenuhan nafkah pakaian yang kurang terpenuhi terdapat pada kasus VI, VIII, IX, dan XII sedangkan pemenuhan nafkah pakaian yang tidak terpenuhi terdapat pada kasus I,II, III, IV,V, XIII dan XIV.

Berdasarkan alasan dari masing-masing kasus tersebut yaitu pemenuhan nafkah pakaian yang terpenuhi karena suami telah mengetahui kewajibannya dalam

${ }^{31}$ Ibid, h. 556.

${ }^{32}$ Zainuddin bin Abdul Aziz al- Malibari al-Fannani,terj, Fațhul Mu`in, jilid II, (Bandung: Sinar BaruAlgensindo, 2005), cet. Ke-3, h. 1447. 
memberi pakaian kepada istri terdapat pada kasus VII, X dan XI. Pada kasus X suami telah memenuhi nafkah pakaian namun istri banyak menuntut kebutuhan lain seperti pakaian baru kepada suami padahal suami ketika itu tidak mampu secara ekonomi.

Pemenuhan nafkah pakaian yang kurang terpenuhi terdapat pada kasus VI satu kali tertunaikan selama 11 tahun, VIII tiga kali tertunaikan selama 11 tahun, IX dua kali tertunaikan selama 23 tahun, XII 2 kali tertunaikan selama 11 tahun. Suami menganggap kebutuhan lain lebih penting, pemberian hanya dikhususkan untuk makan saja bukan pakaian, suami mengabaikannya dan melalaikan kewajibannya dalam memberi nafkah pakaian, karena batas minimal ideal suami memberikan nafkah pakaian adalah satu atau dua kali dalam setahun, sesuai dengan kesepakatan ulama.

Pemenuhan nafkah pakaian yang tidak terpenuhi terdapat pada kasus II selama 30 tahun, kasus III selama 15 tahun dan kasus XIV selama 18 tahun. disebabkan karena suami kurang mampu dan gaji sangat minim. Pada kasus I selama 24 tahun dan kasus IV selama 18 tahun suami tidak memberikan nafkah pakaian karena mendahulukan kebutuhan lain yang lebih penting, menunda dan menganggap remeh memberikan pakaian, sehingga suami melalaikan kewajibannya, sedangkan pada kasus XIII selama 24 tahun, suami tidak memberi nafkah pakaian, karena suami tidak mengetahui bahwa pakaian merupakan kewajiban bagi suami yang harus ditunaikan.

\section{E. Pembahasan}

\section{Nafkah Pakaian yang Terpenuhi}

Pada kasus VII, kasus X dan kasus XI, suami telah menunaikan kewajibannya memberikan pakaian kepada istri dengan pemenuhan yang ideal dua kali pertahun. Allah swt berfirman dalam Q.S. Al- Nahl [16]: 97,

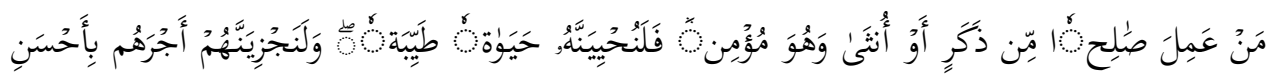

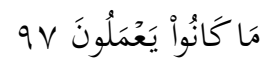

“Barangsiapa yang mengerjakan amal saleh, baik laki-laki maupun perempuan dalam keadaan beriman, maka sesungguhnya akan Kami berikan kepadanya kehidupan yang baik dan sesungguhnya akan Kami beri balasan kepada mereka dengan pahala yang lebih baik dari apa yang telah mereka kerjakan."

Ayat tersebut menjelaskan bahwa terutama bagi seorang suami jika mengerjakan amal shaleh seperti bekerja mencari nafkah untuk keluarganya, maka akan mendapat balasan pahala dari Allah swt sesuai amalan yang dikerjakannya. 
Pemenuhan nafkah pakaian dianggap kurang terpenuhi jika tidak dapat mencukupi kebutuhan istri. Suami memberikan pakaian kepada istri tidak mencapai batas ideal yaitu satu kali atau dua kali pertahun sebagaimana Menurut mazhab AsySyafii dan Mazhab Maliki. Pemenuhan nafkah pakaian yang kurang terpenuhi terdapat pada kasus VI hanya satu kali dalam 11 tahun pernikahannya, karena menganggap kebutuhan lain lebih penting, kasus VIII tiga kali suami memberi pakaian selama 11 tahun, kasus IX dua kali selama 23 tahun dan kasus XII 2 kali selama 11 tahun, suami hanya memberi uang untuk biaya makan saja sehingga suami mengabaikan pakaian istri.

\section{Pemenuhan Nafkah Pakaian yang Tidak Terpenuhi}

Pakaian tersebut salah satu dari nafkah wajib yang harus diberikan suami kepada istri. Permasalahan pada kasus ini, suami menganggap bahwa nafkah pakaian tidak penting diberikan kepada istri karena sebab kelalaian suami, hal ini terdapat pada kasus I selama 24 tahun tidak memberi pakaian dan kasus IV selama 18 tahun, suami bekerja dengan gaji yang terbilang dapat mencukupi kebutuhan istri berupa pakaian.

Ulama sepakat bahwa istri berhak mendapatkan pakaian sebagai kewajiban suami. ${ }^{33}$ Sebagian mereka menyebutkan bahwa suami memiliki kewajiban untuk memberi istrinya pakaian tertentu, sebagaimana Allah swt berfirman dalam Q.S AlBaqarah [2] : 233.

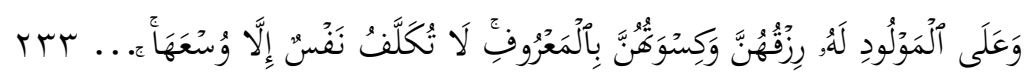

Hukum nafkah pakaian wajib bagi suami diberikan kepada istri, hal ini didasarkan pada kaidah fiqhiyyah:

$$
\text { مالا يتم الواجب إلا به فهو واجب }
$$

"Sesuatu yang menjadikan kewajiban sempurna karenanya adalah wajib"34

Kaidah tersebut menjelaskan bahwa, hukum dari nafkah secara umum adalah wajib, maka pakaian yang bagian dari nafkah tersebut juga menjadi wajib, karena kewajiban menjadi sempurna jika nafkah pakaian itu tertunaikan.

Nafkah adalah kewajiban suami terhadap istri, apabila syarat-syarat untuk mendapatkan nafkah telah terpenuhi. Manakala suami sudah berkewajiban memberi nafkah kepada istri karena sudah memenuhi syarat tetapi kemudian suami tidak Memberikan, istri meminta namun suami mengulur-ngulur, maka suami berdosa dan

${ }^{33}$ Ibnu Hajar al-Asqalani, Fathul Bari, jilid XXVI, terj. Amiruddin, Fathul Bari Syaraḥ Șaḥih, (Jakarta: Pustaka Azzam, 2008), h. 580.

h. 125

${ }^{34}$ Abdul Karim Zaidan, Al-Wajiz, (Jakarta: Pustaka Al-kautṡar, 2008), cet. Ke-1, 
nafkah itu menjadi hutang. Hutang itu tidak gugur kecuali apabila sudah dilunasi atau dibebaskan oleh istrinya. Istri boleh memintanya saat suami kembali kaya. Demikian menurut Mazhab Syafii. ${ }^{35}$

Suami yang memiliki alasan yang jelas bahwa suami tidak menunaikan pakaian karena tidak memiliki kemampuan seperti pada kasus II, kasus III dan kasus XIV, suami memiliki gaji yang minim, sehingga tidak cukup untuk kebutuhan istri berupa pakaian, sedangkan suami sudah berusaha membanting tulang, tapi tetap dalam kondisi suami kurang mampu, maka keadaan ini diperbolehkan, sebagaimana firman Allah dalam Q.S Aț-Ṭhalaq [65]:7

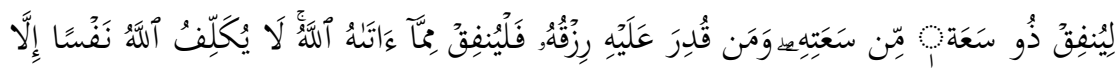

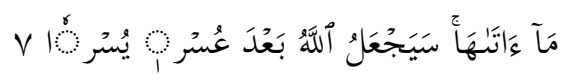

"Hendaklah orang yang mampu memberi nafkah menurut kemampuannya. Dan orang yang disempitkan rezekinya hendaklah memberi nafkah dari harta yang diberikan Allah kepadanya. Allah tidak memikulkan beban kepada seseorang melainkan sekedar apa yang Allah berikan kepadanya. Allah kelak akan memberikan kelapangan sesudah kesempitan."

Berdasarkan firman Allah swt tersebut Allah swt tidak memikulkan beban di luar kemampuan hamba-Nya dan sekadar apa yang Allah swt berikan kepadanya, seperti firman Allah swt, "Allah kelak akan memberikan kelapangan sesudah kesempitan," penggalan ayat ini merupakan janji Allah swt kepada hambanya, bahwa ada waktu dimana suami nanti jika sudah mendapatkan kelapangan rezeki dari Allah maka kewajiban tersebut wajib atas suami dalam memenuhi nafkah pakaian kepada istri. Kaidah fiqhiyyah juga menerangkan bahwa:

\section{“Kesukaran itu menimbulkan adanya kemudahan"36}

Maksud dari kaidah tersebut yaitu apabila suami dalam keadaan sulit dan tidak mampu secara ekonomi dengan pendapatan yang sangat minim sehingga tidak dapat memberikan nafkah pakaian kepada istri, maka adanya kemudahan bagi suami, gugur kewajibannya dalam memberikan pakaian ketika dalam keadaan miskin dan tidak mampu.

Berbeda dengan kasus V dan XIII, suami tidak memberikan pakaian kepada istri dan menganggap pakaian bukan merupakan prioritas yang utama karena sebab ketidaktahuan suami, bahwa pakaian termasuk pemenuhan yang harus ditunaikan,

\footnotetext{
${ }^{35}$ Abdurrahman Al-Juzairi, Fiqih `ala al-Mazahib al-Arba`ah... h. 571.

${ }^{36}$ Nashr Farid Muhammad Washil dan Abdul Aziz Muhammad Azzam, Qawa id
} Fiqhiyyah, (Jakarta: Amzah, 2009), cet. Ke-2, h.55 
seseorang yang tidak tahu adalah tidak adanya ilmu terhadap apa yang semestinya diketahui, dan ini dapat mendatangkan kemudahan. Kaidah fiqhiyyah telah menjelaskan sebagai berikut,

المجهول في الشريعة كا لمعدوم و المعجوز عنه

"Sesuatu yang tidak diketahui dalam syariat seperti sesuatu yang tidak ada dan tidak mampu untuk dilakukan"37

Makna kaidah ini adalah sesuatu yang tidak mampu mengetahuinya, maka menjadi sesuatu yang tidak ada, bagi orang yang tidak mengetahui tidak dihukumi berdosa jika tidak menunaikan kewajibannya.

\section{F. Kesimpulan}

Pemenuhan nafkah pakaian dari suami kepada istri 14 Warga RT. 25 Kelurahan Teritip Kecamatan Balikpapan Timur, dapat di bagi menjadi tiga kelompok. Pertama, tiga kasus nafkah pakaian yang terpenuhi karena faktor suami memiliki penghasilan cukup untuk memenuhi kebutuhan istri dan suami telah mengetahui kewajibannya. Kedua, empat kasus nafkah pakaian yang kurang terpenuhi karena kelalaian suami dalam memberikan nafkah pakaian kepada istri dan menganggap pakaian bukan merupakan kebutuhan yang utama. Ketiga, tujuh kasus suami tidak memenuhi nafkah pakaian kepada istri, di antaranya tiga kasus karena suami memiliki penghasilan sangat minim, dua kasus berikutnya suami telah melalaikannya dan mengabaikan nafkah pakaian istri, kemudian dua kasus karena suami tidak mengetahuinya.

Hukum Islam memandang permasalahan suami yang tidak memberikan nafkah pakaian kepada istri dengan alasan suami menganggap bahwa nafkah pakaian bukan hal yang penting sehingga mendahulukan kebutuhan yang lain, alasan ini tidak dibenarkan dalam syariat karena alQuran dan as-Sunnah telah mewajibkannya, sama halnya dengan kesepakatan para ulama bahwa nafkah pakaian wajib diberikan kepada istri sekali atau dua kali dalam setahun, sesuai dengan kemampuan suami. Allah swt menjajikan pahala bagi suami yang senantiasa menunaikan kewajibannya dan tidak menyia-nyiakan kebutuhan istrinya. Adapun suami yang berpenghasilan

\footnotetext{
${ }^{37}$ Ibid, h. 346
} 
minim dan suami yang tidak mengetahui bahwa nafkah pakaian merupakan kewajiban bagi suami, maka alasan ini tidak bertentangan dan dibenarkan syariat, karena Allah swt tidak membebani hamba yang tidak mampu dan tidak mengetahui. Kewajiban itu akan kembali di tetapkan bagi suami yang mampu dan telah mengetahui hukumnya. 


\section{Daftar Pustaka}

Abu Syuqqah, Abdul Halim. Kebebasan Wanita Jakarta: Gema Insani Press, 1999.

Birulaut. Taufan E. Prast, dan Asma Nadia, Diary Doa Aisyah Putri. Depok: Lingkar Pena, n. d. 14, Google Book.

Majid, Abdul. Pokok-Pokok Fiqh Muamalah dan Hukum Kebendaan dalam Islam. Bandung: IAIN Sunan Gunung Jati, 1986.

as-Sa'di, Abdurrahman bin Nashir. Taisirul Karimirrahman fi Tafsiri Kalamil Mannan, (n.p.: Daruus Salam, 2002), 531.

Ghazaly, Abdurrahman. Fiqh Muamalat. Jakarta: Kencana, 2010.

As-Suyuti, Abdurrohman. Al Asybah Wan Nadho'ir Fi Qowa'idi Wa Furu'i Fiqhis Syafi'iyah, Riyadh: Maktabah Nazzar Al-Baz, 1997.

Hasan, Abu. "Hukum pacaran sebelum nikah dan hukum menolak khitbah/pinangan tanpa alasan," diakses pada 6 Maret, 2019, https://darussalaf.or.id/fatwaulama-tanya-jawab/hukum-pacaran-sebelum-nikah-dan-hukum-menolakkhitbahpinangan-tanpa-alasan/.

Syahidah, Abu. Kamu Hobi Tapi Agama Melarang, Jakarta: Mirqat Media Grafika. 2008. Rif'an, Ahmad Rifai'i. Allah,Inilah Proposal Cintaku, Solo: Gazza Media, 2011.

Al-Dimyati, I'anah al-Thalibin. Semarang: Toha Putra, n.d.

An-Nawawi, al-Majmu' Syarah al-Muhadzdzab.

'Illah, Atho. Selamat Tinggal Pacaran, Selamat Datang di Pelaminan. Jakarta: PT Elex Media Komputindo, 2016. Google Book.

al Insyirah, Daud. Pingin Gaul Malah Digauli. n. p, 2011.

Domain Age Tool, Di akses pada 9 Maret, 2019, www.webconfs.com/webtools/domain-age-tool/.

Eriyanto, Analisis Isi: Pengantar Metodologi untuk Penelitian Ilmu Komunikasi dan Ilmu-ilmu Sosial. Jakarta: Prenadamedia Group, 2015.

Mudjijanti, Fransisca. "Masa Pacaran Dini (Early Dating) dan Dampaknya," diakses pada 6 Maret, 2019, http://eprints.unm.ac.id/10252/2.

Al-Bukhari, Jefri. Sekuntum Mawar Untuk Remaja. Jakarta: Pustaka Al-Mawardi. 2005 Santrock, John W. Adolescence (Jakarta: Penerbit Erlangga, 2003), 239, Google Book. Savourie,Kei. “Menguak Definisi Cinta yang sebenarnya," diakses pada 12 April, 2019, https://kelascinta.com/romansa/menguak-definisi-cinta-yang-sebenarnya.

Kementrian Wakaf dan Urusan Agama Kuwait, Al-Mausu'ah Al-Fiqhiyah AlKuwaitiyah, (Kuwait: Kementrian Wakaf dan Urusan Agama Kuwait , 1983), 40/355-358, eBook pdf. 
Lex dePraxis, "Ini Alasannya Cowok \& Cewek Tidak Bisa Berteman Tanpa Ada Perasaan Lebih!," dipublikasikan oleh Kelas Cinta, 30 Maret 2019, video youtube, 1:38

https://www.youtube.com/watch?v=6GF8I5tzogg

Mustika, M. Shodiq. "About," diakses pada 3 April, 2019, https://pacaranislami.wordpress.com/about/.

Muhammad bin Ahmad Ulaisy, Minah al-Jalil ala Syarh Mukhtasar Khalil (n. p., n. d.) $1 / 223$.

al-Bukhari, Muhammad Ibn Isma'il. Al-Jami' Shahih Bukhari. Beirut: Dar Thauq anNajah, $1422 \mathrm{H}$.

al-Hajjaj, Muslim bin. Shahih Muslim. Beirut: Dar Ihya at-Turats al-'Arabi, n.d.

Musthafa Al-'Adawy, Fiqh al-Akhlaq wa al-Mu'amalat baina al-Mu' minin, trans. Salim Bazemool dan Solihin dan Hafidz341, Loving You, Merit Yuk!. Jakarta: Gema Insani, 2006. Google Book.

Elvigro, Paresma. Catatan Kriuk Untuk Si Single. Jakarta: PT Bhuana Ilmu Populer, 2014.

Pusat Bahasa Departemen Pendidikan Nasional, Kamus Bahasa Indonesia. Jakarta: Pusat Bahasa, 2008. ebook pdf.

http://kaltim.prokal.co/read/news/241331-usia-15-tahun-berhubungan-intim.

ath-Thabrani, Sulaiman Bin Ahmad. Al-Mu'jamul Kabir (Kairo: Dar al-Nasyr Maktabah Ibn Taimiyah, 1415/1994), no.486, 20/211.

Tim Mitra Guru, Ilmu Pengetahuan Sosial Sosiologi. n.p. : PT. Gelora Aksara Pratama, 2007. Google Book.

Tim Penulis Instagram @diary.islami, Jodoh Tak Mau Menunggu. Jakarta: PT Visimedia Pustaka, 2017.

Wahana Komputer, Membuat Toko Online dengan Wordress dan WP eCommerce. Jakarta: PT Elex Media Komputindo, 2015. Google Book.

Wahyuni, Struktur Sosial Pertautan Agama, Budaya, dan Tradisi Sosial. Jakarta: Prenadamedia Group, 2018.

Fitri, Ana Sofiatul. “Pandangan Hakim Terhadap Penentuan Nafkah Akibat Perceraian (Studi di Pengadilan Agama Kota Malang dan Pengadilan Agama Kabupaten Malang) (Tesis, UIN Maulana Malik Ibrahim, Malang). 